\title{
HYDROPOWER: TIME FOR A SMALL MAKEOVER
}

\author{
Gina S. Warren ${ }^{1}$
}

\section{INTRODUCTION}

Over the last several years, hydropower has supplied between 6 and 8 percent of the electricity consumed in the United States. ${ }^{2}$ It is the most abundant, most efficient, and least expensive source of renewable electricity generation on earth. ${ }^{3}$ Yet, when most people think of hydropower they think of huge dams, dead fish, and a destroyed environment. Unfortunately, this perception has on too many occasions been a reality. ${ }^{4}$ Hydropower needs a new PR department. It is time for a "small" makeover.

To embrace the full potential of sustainable hydropower, investors and regulatory agencies must look to develop small, localized facilities on existing infrastructure. Unlike large conventional hydropower, small and low flow hydropower facilities require less water flow and can be placed in conduits, canals, locks, and other areas that are less affected by climate change decreases in river levels. ${ }^{5}$ The environmental impact of small hydropower is generally minimal. ${ }^{6}$ It diverts less water, and does not require creation of dams and reservoirs. ${ }^{7}$ Furthermore, small hydropower can be developed near populated areas, especially if located on existing infrastructure, which makes it a valuable distributed generation energy source. This Article will discuss some of the advantages of distributed generation over centralized generation. Distributed generation is generally cost-efficient and environmentally-friendly because it takes up very little space and requires little to no construction of transmission and distribution systems. ${ }^{8}$ It is also less susceptible to blackout and damage as a result of storms, which are becoming more frequent and severe due to a changing

1. Associate Professor of Law, Texas A\&M University School of Law.

2. U.S. Energy Information Administration, ELECTRIC POWER MONTHLY, $\mathrm{http}: / /$ www.eia.gov/electricity/monthly/epm_table_grapher.cfm?t=epmt_1_1 (last visited Jan. 11, 2014, archived at http://perma.cc/LUUD7-B335).

3. See generally Ned Haluzan, Why is Hydroelectricity Good Source of Energy?, HYDRO EARTH (Oct. 5, 2012, 4:24 AM), http://hydroearth.blogspot.com/2012/10/why-ishydroelectricity-good-source-of.html, archived at http://perma.cc/8ELK-J33L.

4. DANIEL R. MANDELKER, NEPA LAW AND LITIG., $\S 10: 35$ DAMS AND RESERVOIRS (2013).

5. Dr. Anne Wheldon, Micro-Hydro, ASHDEN, http://www.ashden.org/micro-hydro (last visited Jan. 11, 2014, archived at http://perma.cc/86JJ-LUNZ).

6. Id.

7. Id.

8. Sanya Carley, Distributed Generation: An Empirical Analysis of Primary Motivators, 37 ENERGY POL'Y 1648, 1648-49 (2009). 
climate. $^{9}$

In addition to guidance on locating these small facilities, regulatory agencies should continue to take steps to allow a more streamlined licensing scheme for small hydropower. The current licensing scheme requires-with few exceptions - that small projects undergo the same complex licensing process as large projects, such as construction of another Hoover Dam. ${ }^{10}$ The process is expensive-costing several times that of the technology itself. ${ }^{11}$ The process is time-consuming-often taking up to five years to complete. ${ }^{12}$ It requires multiple levels of consultation—often with dozens of parties. ${ }^{13}$ And, all of this must occur prior to issuance of a license to operate. ${ }^{14}$ As will be discussed, the federal government and some states have taken steps to make the process more efficient; however, more can and should be done.

\section{NON-POWERED CONDUITS, LOCKS, AND DAMS, OH MY.}

Over the last several years, the federal government has studied the benefits and potential of small hydropower development. Multiple reports have been issued and it has become clear that there are literally hundreds of thousands of feasible sites for hydropower development in the United States that, if developed, could produce a significant amount of clean sustainable electricity.

In 2006, the Department of Energy reported that there are roughly 500,000 sites across the United States suitable for small hydropower development, with some 130,000 sites feasible for immediate development. ${ }^{15}$ The report assumed that only small or low power

9. U.S. DeP'T OF ENERgy, The Potential Benefits of Distributed GenERation aNd RATE-RELATED ISSUES THAT MAY IMPEDE ThEIR EXPANSION iii (2007) [hereinafter U.S. DEP'T OF ENERGY, BENEFITS OF DISTRIBUTED GENERATION], archived at http://perma.cc/D2YM-XHW7.

10. Gina S. Warren, Hydropower: It's a Small World After All, 91 NEB. L. REv. 925, 958-65 (2013) (analyzing the complexities of the current regulatory and licensing scheme for hydropower).

11. Id. at 968 .

12. Id.

13. Lea Kosnick, The Potential for Small Scale Hydropower Development in the US, 38 ENERGY POL'Y 5512, 5518 (2010), archived at http://perma.cc/U7BS-NTV4.

14. Fed. Energy Regulatory Comm'n, Handbook for Hydroelectric Project LICENSING AND 5 MW EXEMPTIONS FROM LICENSING 2-1 (2004), archived at http://perma.cc/S88P-XU2M.

15. U.S. DEP'T OF ENERgY, FEASIBILITY ASSESSMENT OF THE WATER ENERgY Resources of tHe United States for New Low POWER aNd SMAll Hydro Classes of HydRoEleCtric Plants 21 (2006) [hereinafter FEASIBILITY Assessment] ("The nearly 130,000 feasible potential projects identified in the study were classified as either low power (hydropower potential less than $1 \mathrm{MWa}$ ) or small hydro (hydropower potential greater than or equal to $1 \mathrm{MWa}$, but less than or equal to $30 \mathrm{MWa}$ )."). 
hydropower facilities would be developed on the sites and that the facilities would not require construction of dams or reservoirs. ${ }^{16}$ If developed, the close to 130,000 feasible sites "had a total gross power potential of nearly $100,000 \mathrm{MWa}$ " and could "realistically offer $30,000 \mathrm{MWa}$ of hydropower potential. ${ }^{\prime 17}$ However, as pointed out in the study, it is unrealistic that all 130,000 project sites will be developed anytime in the near future ${ }^{18}$ more realistic are the top 5,400 sites for new small hydropower facilities, which "represent nearly 20,000 MWa of hydropower potential." 19 Twenty thousand MWa translates into an "increase in U.S. annual hydropower generation by more than $50 \% . " 20$

To put this in context, a power generator with a capacity of one megawatt-generating $8,760 \mathrm{MWh}$ per year-is capable of powering approximately 800 homes, based on the average household power consumption across the United States. ${ }^{21}$ At 800 homes per megawatt of capacity, a 20,000 megawatt power generation increase could result in powering as many as sixteen million homes with renewable energy. The report concludes "beneficial renewable water energy resources are under utilized throughout most of the country" and that 41 states could benefit by development of small or low power hydropower. ${ }^{22}$

In 2010, the U.S. Department of Energy; Department of the Interior, through the Bureau of Reclamation; and the Department of the Army, through the U.S. Army Corps of Engineers, entered into a Memorandum of Understanding for Hydropower. ${ }^{23}$ The purpose of the Memorandum of Understanding was to promote "environmentally sustainable hydropower"

16. $I d$.

17. Id. at $22-23$.

18. Id.

19. Id. at 23 .

20. 1 .

21. Average power consumption for a household in the United States is $908 \mathrm{kWh}$ per month (10.9 MWh per year). See Table 5A. Residential Average Monthly Bill by Census Division, and State, U.S. ENERGY INFO. ADMN., http:/www.eia.gov/electricity/ sales_revenue_price/html/table5_a.html (last visited Jan. 11, 2014, archived at http://perma.cc/Z5RZ-GWX8); see also Bob Bellemare, What is a Megawatt?, CoMmoditiES Now (Mar. 2010), http://www.commodities-now.com/reports/power-andenergy/2136-what-is-a-megawatt.html, archived at http://perma.cc/Y4XE-R4R8.

22. FEASIBILITY ASSESSMENT, supra note 15 , at 35.

23. U.S. DEP'T OF ENERGY ET AL., MEMORANDUM OF UNDERSTANDING FOR HYDROPOWER AMONG THE DEP'T OF ENERGY, THE DEP'T OF THE INTERIOR AND THE DEP'T OF THE ARMY (2010) [hereinafter MEMORANDUM OF UNDERSTANDING], archived at http://perma.cc/4ARF-K8A4. The U.S. Army Corp of Engineers and the Department of Interior are the largest owners and generators of hydropower in the United States, with a combined generation of about $34,000 \mathrm{MW}$, or about half of the U.S. hydropower. Weekly Clean Energy Roundup: March 31, 2010, SUSTAINABLEBUSINESS.COM (Mar. 31, 2010, 1:06 PM), http://www.sustainablebusiness.com/index.cfm/go/news. feature/id/1787/page/2, archived at http://perma.cc/XMZ7-TFHV. 
development in the United States. ${ }^{24}$ The Memorandum of Understanding required the parties to conduct studies to determine the best locations for development. ${ }^{25}$ The studies were to identify existing and future, federal and non-federal sites with (1) the fewest stakeholder obstacles to development, ${ }^{26}$ (2) that would be least negatively affected by climate change, and (3) where generation would most readily and efficiently be integrated into the grid. ${ }^{27}$

The first report, submitted in March 2011, in accordance with the Memorandum of Understanding assessed the feasibility of development at existing Bureau of Reclamation facilities. ${ }^{28}$ The report assessed 530 sites previously identified by Reclamation for potential hydropower development. ${ }^{29}$ The March 2011 report stated that of the 530 federal sites, none of which had existing hydropower facilities, 191 "were determined to have some level of hydropower potential" ${ }^{\prime 30}$ and 70 "could be economically feasible to develop."31 Reclamation noted that many of the potential sites fell into a "gray area of being economically feasible." to a lack of federal and state incentives for hydropower development, which "can contribute substantially to the economic viability of a project." such, to support hydropower development, Reclamation believed its analysis could be used to "support an incentive program for hydropower as a renewable energy source." 34

In follow-up to the March 2011 report, the Bureau of Reclamation "analyzed the hydropower potential of all [530] sites regardless of size ...

24. Memorandum of Understanding, supra note 23, at 1 . The stated Mission of the Memorandum of Understanding is that the parties would use their resources to work together to:

(1) support the maintenance and sustainable optimization of existing Federal and non-Federal hydropower projects, (2) elevate the goal of increased hydropower generation as a priority of each Agency to the extent permitted by their respective statutory authorities, (3) promote energy efficiency, and (4) ensure that new hydropower generation is implemented in a sustainable manner.

Id. at 2.

25. Id. at 10.

26. These barriers include "potential regulatory constraints related to water supply, fish and wildlife considerations, and effects on Native Americans, water quality, and recreation." BUREAU OF REClamation, DeP'T OF THE INTERIOR, RECLAMATION, MANAGING WATER IN THE WEST: HYDROPOWER RESOURCE ASSESSMENT AT EXISTING RECLAMATION FACILITIES ES-4 ES-5 (201 1), archived at http://perma.cc/AP6S-HQUM.

27. See MEMORANDUM OF UNDERSTANDING, supra note 23.

28. BUREAU OF RECLAMATION, supra note 26.

29. U.S. DEP'T OF THE INTERIOR ET AL, POTENTIAL HydRoEleCtric DEVELOPMENT AT EXISTING FEDERAL FACILITIES 7 (2007), archived at http://perma.cc/8HVL-BJJX.

30. BUREAU OF RECLAMATION, supra note 26 , at ES-1.

31. Id. at ES-6.

32. Id.

33. Id.

34. Id. 
[and] incorporated updated economic and technical analysis including detailed turbine selections, green incentives, proximity to transmission, and analysis of regulatory/environmental constraints." ${ }^{\text {35 }}$ In March 2012, it issued a supplement to its original report concluding that " $268 \mathrm{MW}$ and 1.2 million MWh of energy could be produced annually at existing Reclamation facilities if all 191 sites with the technical potential for development were developed." ${ }^{36}$

An April 2012 report issued by the U.S. Department of Energy assessed the potential of hydropower development at existing non-powered dams. ${ }^{37}$ Of the roughly 82,500 dams across the United States, only about 2,500 dams are used to generate electricity. ${ }^{38}$ The remaining eighty-some thousand dams are non-powered. ${ }^{39}$ The report analyzed a subset of these 80,000 dams to determine their generation potential if hydroelectric facilities were placed on them. ${ }^{40}$ The report begins with the general hypothesis that costs have already been expended and environmental impacts have already been incurred, so there is very little disincentive to development on these sites. ${ }^{41}$ The authors acknowledged, however, that "detailed studies of site-specific costs and impacts will be required to test this hypothesis. ${ }^{, 42}$ After accounting for a variety of physical and hydrological factors, the report estimated development on some 54,000 non-powered dams could result in a 15\% increase in the existing conventional hydropower generation in the U.S. ${ }^{43}$ Whittling down the 54,000 , the report identified 597 non-powered dams that provided $90 \%$ of the generation increase, each having a potential generation in excess of 1 MW. ${ }^{44}$ The majority of the best sites were in regions not traditionally known for hydropower production-such as Ohio River Basin, Upper Mississippi, and Arkansas-and were "located at navigation locks and

35. Bureau of Reclamation, Dep't of the Interior, Reclamation, Managing WATER IN THE WEST: SITE INVENTORY AND HYDROPOWER ENERGY ASSESSMENT OF RECLAMATION OWNED CONDUITS 1 [hereinafter WATER IN THE WEST] (2012), archived at $\mathrm{http}: / /$ perma.cc/T95R-G4NW (alteration added).

36. Id.

37. Boualem Hadjerioua ET AL., OAK Ridge NaT'L Lab., AN ASSESSMENT OF ENERgY Potential at NON-POWERED DAMS IN THE UNITED STATES vii (2012), archived at http://perma.cc/G6JF-8YQQ.

38. Id.

39. Id. The dams are instead used for such things as water supplies, inland navigation, and flood control. Id. at 5 .

40. Id.

41. Id.

42. Id.

43. Id. at 22 ("At the current phase of assessment, the total potential capacity and annual generation are estimated to be, respectively, $12 \mathrm{GW}$ and 45 terawatt hours (TWh) per yeararound $15 \%$ of the existing U.S. conventional hydropower total.").

44. Id. (identifying twenty-five sites that would alone account for $40 \%$ of the increase). 
dams located on relatively big rivers., ${ }^{, 45}$

\section{SUSTAINABLE SMALl AND LOW Flow HydROPOWER DEVELOPMENT}

These reports from the Department of Energy and the Bureau of Reclamation identify the abundance of feasible sites for small hydropower development. This Article posits, however, that new small hydropower facilities should be located on existing non-powered infrastructure. The best sites will not cause any additional negative environmental impacts, and will be located in a close proximity to the end user. Small and low flow hydropower can provide significant amounts of decentralized electricity. ${ }^{46}$ Toward that end this Article recommends that private and public investors and licensing agencies (1) focus on development of existing non-powered conduits, canals, locks, and dams that can provide an increase in hydropower generation without significant additional infrastructure costs, and without additional environmental impacts, depending on the technology used, and (2) consider that the best sites for development are located close to the customer base, because no or little transmission infrastructure would be needed, and the facilities would be less susceptible to a changing climate and large-scale blackouts.

An equally important step, however, is the need for a more streamlined licensing process. Congress recently passed, and the President signed into law, two hydropower acts that will help facilitate development of certain projects-especially those to be located on conduits. ${ }^{47}$ However, more changes can and should be made. In particular, states should take a bigger role, possibly through memorandums of understanding with the Federal Energy Regulatory Commission, in licensing small hydropower. This is especially beneficial if the facilities will be located on existing infrastructure, for the purpose of providing local electricity generation.

\section{A. Developing on Existing Non-Powered Infrastructure Located Near Populated Areas}

To be sustainable, the small hydropower facilities should be located on existing infrastructure and in close proximity to population centers.

45. Id. at 24. This is an important point "[b]ecause locks and dams were built mainly for navigation purposes instead of municipal water supply and irrigation, [and] there may be less concern about impacts regarding other competing water usage." $I d$. at 23 (alterations added).

46. EPU-NTUA, EXeCUTIVE SUMMARY ON SMALl HYDRO 6 (2008), archived at http://perma.cc/PDQ9-3N2T. Small hydropower can be a nice compliment to distributed generation from solar and wind due to its generally more consistent flow. Id. at 3 .

47. See David A. Fitzgerald \& Monica M. Berry, New Legislation to Streamline Smallscale Hydropower Development, FIERCE ENERGY (Sept. 10, 2013), http://www.fierceenergy. $\mathrm{com} /$ story/new-legislation-streamline-small-scale-hydropower-development/2013-09-10, archived at $\mathrm{http}: / / \mathrm{perma} . \mathrm{cc} / 5 \mathrm{AGK}-7 \mathrm{WEC}$. 
Utilizing existing infrastructure would allow for a significant increase in hydropower generation without additional construction costs and without adding to existing environmental impacts. ${ }^{48}$ It is not only important that the facilities be located on existing infrastructure, it is important that they be located near population centers. Utilizing small and low flow hydropower as a distributed generation energy source would ensure customers are receiving environmentally-friendly, low-cost, renewable energy that is less susceptible to outages caused by increasingly severe storms.

The most feasible locations to develop hydropower are on existing non-powered dams, conduits, canals, and locks because for the most part, the infrastructure has already been built, and the environmental damage has already been committed. ${ }^{49}$ As noted previously, there are thousands of existing unpowered dams ${ }^{50}$ and hundreds of existing unpowered conduits ${ }^{51}$ in the U.S. that have the potential to generate electricity. Furthermore, new technological advancements are underway for the specific purpose of generating power on these existing conduits, canals, pipelines, dams, and locks. ${ }^{52}$ The focus has been on flexible, low cost technology with low potential for environmental impacts. ${ }^{53}$ Referring to conduit development, the Bureau of Reclamation noted that the advances in technology "could significantly decrease the costs of development, operation and maintenance at these sites and subsequently increase their economic viability." ${ }^{54}$ Toward that end, in April 2011, the Department of Energy and the Department of Interior announced they would offer "financial assistance to projects that develop and demonstrate innovative hydropower technologies that can produce power more efficiently, reduce costs, and increase sustainable

48. No doubt one could envision a situation in which the addition of a power-producing mechanism to an existing structure could increase environmental impacts. It is not this author's intent to ignore that potential for abuse. Instead, the intended goal is to utilize existing infrastructure in an attempt to prevent new environmental damage. As always, regulatory agencies must keep a watchful eye on technologies to ensure environmental sustainability.

49. Prior to placing power producing facilities on an existing structure, a site-specific analysis should be done to prevent any additional environmental damage.

50. BOUALEM HADJERIOUA ET AL., supra note 37.

51. WATER IN THE WEST, supra note 35.

52. Departments of Energy and Interior Award Nearly $\$ 17$ Million for Advanced Hydropower Technologies, U.S. DEP'T OF ENERGY (Sep. 6, 2011, 2:30 PM), http://energy. gov/articles/departments-energy-and-interior-award-nearly-17-million-advanced-hydropowertechnologies, archived at http://perma.cc/9K78-33ZL.

53. See U.S. DeP'T OF ENERgy, WATER POWER For a CleAN ENERgy Future 10 (2013) [hereinafter CLEAN ENERGY FUTURE], archived at http://perma.cc/L7C4-8BHU ("Potential environmental impacts also tend to be low as the devices are often deployed in man-made environments such as canals, pipes, or locks and dams.").

54. WATER IN THE WEST supra note 37 , at 6 . 
hydropower generation at sites not previously considered practical."${ }^{, 55}$ Sixteen projects were chosen to receive nearly $\$ 17$ million in financial assistance. $^{56}$

In addition to utilizing existing infrastructure, the best sites for development are those that would qualify as distributed generation, located in close proximity to the end user. Facilities developed at or near the customer tend to produce less expensive, more reliable, and more environmentally-friendly electricity. ${ }^{57}$ The facilities tend to be less expensive and more environmentally-friendly because they are smaller and require little to no additional transmission and distribution infrastructure. ${ }^{58}$ The facilities tend to be more reliable because they require less infrastructure and are less susceptible to recurrent, severe storms and largescale blackouts. ${ }^{59}$ Distributed generation utilizes micro-level transmission and distribution grids and as a result, electricity transmitted on these smallscale grids does not rely upon a central, interconnected system. ${ }^{60}$ Instead, several small facilities are distributed throughout the populated area and if a storm knocks out electricity to one facility, the entire geographical area does not lose electricity. ${ }^{61}$ With the rise of more severe and frequent storms due to climate change, ${ }^{62}$ distributed generation can provide sustainable, reliable electricity generation without succumbing to large-scale blackouts. ${ }^{63}$ Superstorm Sandy provides a good example of the resilience of

55. U.S. ARMY CORPS OF ENG'RS ET AL., MEMORANDUM OF UNDERSTANDING FOR HYDROPOWER: TWO-YEAR PROGRESS REPORT 14 (2012), archived at http://perma.cc/ZP5F$\mathrm{XY} 3 \mathrm{~N}$.

56. Id. ("Of those awards, two grants were for technology testing and demonstration at Reclamation sites, and DOE and Reclamation have partnered to co-fund and monitor the work occurring through those projects."); see also 16 Projects To Advance Hydropower Technology, DEP'T OF ENERGY (Sep. 6, 2011), http://energy.gov/articles/16-projectsadvance-hydropower-technology, archived at http://perma.cc/CQ4B-MARD (detailing a list of the projects); U.S. ARMY CORPS OF ENG'RS ET AL., supra note 55, at 29-31 (giving details on the installed technology).

57. See generally U.S. DEP'T OF ENERGY, BENEFITS OF DISTRIBUTED GENERATION, supra note 9.

58. Carley, supra note 8.

59. U.S. DEP'T OF ENERGY, BENEFITS OF DISTRIBUTED GENERATION, supra note 9.

60. Sara C. Bronin, Curbing Energy Sprawl with Microgrids, 43 CoNN. L. REv. 547, 561-62 (2010) (discussing the problem of energy sprawl and why microgrids and distributed generation are a compelling alternative to large centralized generation).

61. U.S. DEP'T OF ENERGY, BENEFITS OF DISTRIBUTED GENERATION, supra note 9, at 1-6, $1-7$.

62. Climate Change Study Shows an Increase in Natural disasters in North America, UNEP RONA NEWSLETTER, Jan. 2013, at 2 (UNEP RONA is the acronym for the U.N. Environmentt Programme, Regional Office for North America, Washington, D.C.).

63. N.Y. STATE 2100 COMm'N, ReCOMmendations to ImPROVE the StRENGTH AND RESILIENCE OF THE EMPIRE STATE'S INFRASTRUCTURE 95 (2013), archived at 
distributed generation.

In October 2012, Superstorm Sandy caused significant damage to energy delivery infrastructure in the Northeast resulting in more than eight million households losing power for more than a week. ${ }^{64}$ Yet during that same time, in the midst of the darkness, several small generation plants provided heat and light to first responders and to those in need. ${ }^{65}$ For example, New York University's 14.4 MW combined cycle CHP system, installed in 2010, kept power throughout the storm giving evacuees a place to stay and New York City officials a location for a command post. ${ }^{66}$ After the disaster, New York Governor Andrew Cuomo convened a commission, named the NYS 2100 Commission, "to examine and evaluate key vulnerabilities in the State's critical infrastructure systems, and to recommend actions that should be taken to strengthen and improve the resilience of those systems. ${ }^{, 67}$ The Commission made several recommendations, including a recommendation that the State look to increase power generation from distributed energy sources. ${ }^{68}$ According to the Commission: "Utilizing distributed generation resources, or on-site power generation, reduces dependence on the electric distribution system that is susceptible to damage during a natural disaster." ${ }^{\prime 69}$

Ample potential hydropower sites across the United States could provide localized generation of electricity. As noted earlier, the Department of Energy identified some 130,000 sites that were feasible for small hydropower development. ${ }^{70}$ Utilizing the following criteria, 5,400 of those 130,000 became particularly appealing:

- Hydropower potential $\geq 10 \mathrm{kWa}$

- Does not lie within a zone in which development is excluded by federal law or policy

- Does not lie within a zone that makes development highly unlikely because of land use designations

http://perma.cc/63UF-Q64Z ("Utilizing distributed generation resources, or on-site power generation, reduces dependence on the electric distribution system that is susceptible to damage during a natural disaster.").

64. SuperStorm Sandy Raises Climate Change Political Profile, UNEP RONA NEWSLETTER, Jan. 2013, at 3 (UNEP RONA is the acronym for the U.N. Env't Programme, Reg'l Office for N. Am., Washington, D.C.).

65. ICF INT'L, COMBINED HEAT AND POWER: ENABLING RESIllent ENERGY INFRASTRUCTURE FOR CRITICAL FACILITIES 13-30 (2013), archived at http://perma.cc/TRSN5T5D.

66. Id. at 29.

67. NEW YORK STATE 2100 COMMISSION, supra note 63, at 10.

68. Id. at 15, 97-100.

69. Id. at 95 .

70. U.S. DEP'T OF ENERGY, FEASIBILITY ASSESSMENT, supra note 15, at 22-23. 
- Does not coincide with an existing hydroelectric plant

- Is within 1 mile of a road

- Is within 1 mile of part of the power infrastructure (power plant, power line, or substation) $O R$ is within a typical distance from a populated area for plants of the same power class in the region ${ }^{71}$

The criterion for being one mile or less from a road lowers the cost of constructing additional infrastructure, which can make a new facility economically unviable. ${ }^{72}$ Interestingly, the study found that this factor was not "very restrictive, because proximity analysis revealed that $84 \%$ of the available resource sites were within 1 mile of a road." ${ }^{73}$ Rather than just being a cost-prohibitive concern, the distance from existing power infrastructure and populated areas was instead "based on the distance of most of the existing hydroelectric plants in each power class (low power or small hydro) to a city or population center., ${ }^{74}$ Analysis showed that approximately $90 \%$ of the potential sites were located less than ten miles of a populated area. ${ }^{75}$ In fact, the majority of the sites are five miles or less from a city center. ${ }^{76}$ Likewise, the Bureau of Reclamation's site inventory of Reclamation owned conduits showed that of the 544 conduits available for development, less than 50 were greater than two miles from a distribution or transmission line. ${ }^{77}$

States should take this as an opportunity to recognize, and to promote, the potential of small hydropower as a viable renewable distributed energy source. The Governor of the state of Rhode Island did just that on July 11, 2013, when he signed into law an act that looks to promote the utilization of small hydropower to meet Rhode Island's distributed generation goals. The

71. Id. at 14-16 (emphasis added). Environmentally sensitive areas were also excluded as potential sites. Id. ("The question of whether site development was highly unlikely due to federal land use designation or environmental sensitivities was answered by intersecting the stream reaches corresponding to water energy resource sites with the polygons corresponding to the exclusion zones using [geographic information system] tools.").

72. Id. at 16 .

73. Id.

74. Id. ("The feasibility criterion in this case was based on actual locations of hydroelectric plants rather than an assumed economic limitation as with the construction of an access road or hook up to a transmission line.").

75. Id. at $16-17$.

76. Id. at 17, fig. 10(a). Of the twenty regions utilized by the Department of Energy, ninety percent of the low power plant sites in regions 1-9,12,13,15, and 20 are located five miles or less from a populated region, and ninety percent of the small hydropower plant sites in regions $1-3,6-9,11,13,16$, and 20 are located five miles or less from a city. Id. at 17 , tbl. 3.

77. WATER IN THE WEST, supra note 35. 
Act includes, for the first time, specific language with regard to small hydropower and its importance as a renewable distributed energy resource. ${ }^{78}$ In essence, Rhode Island requires electric distribution companies to solicit proposals once a year from local, renewable energy developers, including developers of small hydropower. ${ }^{79}$ So long as the proposals are "commercially reasonable," the distribution companies must purchase the energy pursuant to standardized long-term contracts (with fixed prices), as specifically set forth under the Act. ${ }^{80}$ William $\mathrm{H}$. Ferguson, executive director of The Energy Council of Rhode Island, stated that the changes "will help to provide lower cost renewable energy . . . and establish[] a process for the development of small scale hydro power, which is expected to be a lower cost renewable energy option." ${ }^{\prime 81}$ The Act requires the Rhode Island's Office of Energy Resources to prepare an annual report identifying the impact of the Act on jobs, the economy, the environment, and system reliability, among other things. ${ }^{82}$ It will be interesting to read about those benefits, especially as they relate to development of small hydropower, in

78. Interestingly, the Act acknowledges the lengthy process for development of hydropower and provides an additional 30 months for small hydropower to reach the required output under a distributed generation contract. The language of the Act provides, in part, that standard power purchase agreements for distributed generation must generally allow a qualifying distributed generation facility eighteen months to become $90 \%$ operational, with the exception of hydroelectric facilities, which are allowed forty-eight months. S. Res. 641, 2013 Leg., Jan. Sess. (R.I. 2013), archived at http://perma.cc/HPC93CVE. The contracts must:

Provide that if the distributed generation facility has not generated ninety percent $(90 \%)$ of the output proposed in its enrollment application within eighteen (18) months after execution of the contract, the contract shall be terminated and the performance guarantee shall be forfeited. An eligible smallscale hydropower distributed generation facility that has not generated ninety percent $(90 \%)$ of the output proposed in its enrollment application within forty-eight (48) months after execution of the contract shall result in the contract being terminated and the performance guarantee being forfeited. Any forfeited performance guarantee deposits shall be credited to all distribution customers in rates and not retained by the electric distribution company.

Id. (emphasis on new language of Act added).

79. Id.

80. Id.

81. Press Release, Legislative Press \& Information Bureau, R.I. State House, Legislation Seeks to Keep Energy Costs in Check (Mar. 6, 2013), archived at http://perma.cc/9TLH-89SG. Another advantage in utilizing small hydropower is that it is a great compliment to distributed generation from sources such as solar and wind, due to its generally more consistent flow. See O.A. Jaramillo et al., Using Hydropower to Complement Wind Energy: A Hybrid System to Provide Firm Power, 29 RENEWABLE ENERGy 1887-1909 (2004) (analyzing the feasibility of utilizing hydropower in conjunction with wind to provide firm power).

82. S. Res. 641, 2013 Leg., Jan. Sess. (R.I. 2013), archived at http://perma.cc/HPC93CVE. 
the coming years.

\section{B. Revamping the Licensing Scheme}

Equally important to the need to ensure that the development is sustainable is the need for a workable licensing program. Pursuant to the Federal Power Act, the Federal Energy Regulatory Commission (FERC) has the authority to issue licenses and regulate development of hydropower facilities. ${ }^{83}$ The licensing process is long - "considerably longer than that of other energy resources, such as wind or natural gas"-and is expensive. ${ }^{84}$ Regardless of the size of the facility, the licensing process can take up to five-and-a-half years to complete and can cost thousands of dollars. ${ }^{85}$ As discussed in detail in a previous article, "[t]he most significant barrier to efficient and economic licensing appears to be the pre-application and postapplication consultation requirements. ${ }^{, 86}$ Dozens of stakeholders can be involved in the licensing process, each generally having a different vision for development (or lack thereof) of the waterway. ${ }^{87}$ While large conventional hydropower projects that require construction of dams and reservoirs should certainly undergo extensive scrutiny, small projects are not similarly situated and should not be treated equally regarding licensing. Small or low power hydropower facilities can be developed without reservoirs and dams, and in many instances can be placed on existing infrastructure, such as canals, conduits, pipelines and non-powered dams, thereby minimizing environmental impacts. ${ }^{88}$

Very recently, Congress passed two acts that will help alleviate some of these licensing concerns. The Hydropower Regulatory Efficiency Act has

83. See Federal Power Act, 16 U.S.C. $\$ 797$ (2005).

84. The American Energy Initiative: Hearing on the Hydropower Regulatory Efficiency Act of 2012 Before the H. Energy \& Power Subcomm., 112th Cong. 12 (2012) [hereinafter Testimony of Andrew Munro] (statement of Andrew Munro, Past President of the Nat'l Hydropower Ass'n), archived at http://perma.cc/66YE-MH24.

85. Id. at 12-13; see also National Water Resources Association position on FERC Exemption - Small In-conduit Hydropower, NAT'L WATER RES. Ass'N, http://www.nwra. org/issues/ferc-exemption-small-conduit-hydropower/ (last visited Jan. 11, 2014, archived at http://perma.cc/VN8Q-79SB) (discussing that even with the FERC small hydropower exemption, project costs can reach $\$ 100,000)$.

86. Warren, supra note 10 , at 969 .

87. Dr. Kaveh Madani discusses the lengthy hydropower licensing process in his Article entitled, Hydropower Licensing and Climate Change: Insights from Cooperative Game Theory, 34 ADVANCES IN WATER RESOURCES 174-83 (2011). He opines that much of the delay in licensing comes from the stage 3 consultation phase, because stakeholders are unable to reach agreement on the proceedings due to their various (and often contrary) interests. Dr. Madani proposes revising FERC's licensing framework to utilize the cooperative game theory so as to appropriately incentivize stakeholders to negotiate, and thereby reduce delay.

88. Warren, supra note 10 , at 956. 
been before Congress in one form or another for the last three years. ${ }^{89}$ This year, the Act finally made it through both Houses-with overwhelming bipartisan support-and was signed into law by President Obama on August $9,2013 .^{90}$ Among other benefits, ${ }^{91}$ the Act makes two significant changes for hydropower licensing and development.

First, it amends the Federal Power Act to exempt certain qualifying conduit hydropower facilities from FERC licensing altogether. ${ }^{92}$ To qualify, the conduit hydropower facility must meet several criteria. For example, it cannot have an installed capacity of greater than five $\mathrm{MW}$, and it cannot utilize a dam or other impoundment. ${ }^{93}$ Furthermore, the Act applies only to those facilities to be located on non-federally owned conduits, and to those facilities not previously licensed or exempted under the Federal Power Act. $^{94}$

Applicants seeking to construct a qualifying facility must file a notice of intent with FERC detailing how the facility meets the qualifying

89. See Senate Energy Committee Passes Hydroelectric Power Bills to Full Senate for Voting, HYRDOWORLD (May 8, 2013), http://www.hydroworld.com/articles/2013/05/senateenergy-committee-passes-hydroelectric-power-bills-to-full.html, archived at http://perma.cc/ CD77-8YL6.

90. Hydropower Regulatory Efficiency Act of 2013, Pub. L. No. 113-23, 127 Stat. 493 (2013) (codified in scattered sections of 16 U.S.C.). The bill unanimously passed the House on February 13, 2013, and the Senate on August 1, 2013. See H.R. 267: Hydropower Regulatory Efficiency Act of 2013, GovTRACK.Us, https://www.govtrack.us/congress/bills/ 113/hr267, archived at $\mathrm{http}: / /$ perma.cc/YB7L-Q6ZY

91. The Act will:

Increase the small hydro exemption from $5 \mathrm{MW}$ to $10 \mathrm{MW}$

Remove conduit projects under $5 \mathrm{MW}$ from FERC jurisdiction

Increase the conduit exemption to $40 \mathrm{MW}$ for all projects

Provide FERC the ability to extend preliminary permits

Require FERC to examine a two-year licensing process for non-powered dams and closed-loop pumped-storage

Hydropower Regulatory Efficiency Act of $2013 \S \S 1-7$.

92. Id. $\S 4(\mathrm{a})(1)$. The Act defines "conduit" as "any tunnel, canal, pipeline, aqueduct, flume, ditch, or similar manmade water conveyance that is operated for the distribution of water for agricultural, municipal, or industrial consumption and not primarily for the generation of electricity." Id.

93. Id. The Act also allows FERC to "grant an exemption in whole or in part" to projects that will have an installed capacity up to 40 megawatts. Id.

94. Id. The Act applies where:

the facility is constructed, operated, or maintained for the generation of electric power and uses for such generation only the hydroelectric potential of a non-federally owned conduit;

the facility has an installed capacity that does not exceed 5 megawatts; and on or before the date of enactment of the Hydropower Regulatory Efficiency Act of 2013, the facility is not licensed under, or exempted from the license requirements contained in, this part. 
criteria. ${ }^{95}$ FERC then has fifteen days to make a determination whether the facility meets the criteria and if so, FERC must notify the public of the notice of intent. ${ }^{96}$ Interestingly, the language of the Act states that "an entity" then has forty-five days to contest "whether the facility meets the qualifying criteria. ${ }^{, 97}$ It is unclear why the Act is written in this manner, but it would presumably allow the public to contest the criteria and not just an entity. In any event, it is clear that the only thing that can be contested is whether the project meets the qualifying criteria, and not whether it should be developed in the first place. ${ }^{98}$ As such, it appears that if the facility qualifies for the exemption, development cannot be blocked by FERC under the Federal Power Act.

Second, the Act proposes to "improve the regulatory process and reduce delays and costs for hydropower development at nonpowered dams and closed loop pumped storage projects." ${ }^{.99}$ In particular, it requires FERC to "investigate the feasibility of the issuance of a license for hydropower development at nonpowered dams and closed loop pumped storage projects in a 2-year period." ${ }^{, 100}$ Within sixty days, FERC will hold a workshop and "solicit public comment and recommendations."101 It will work to develop criteria for a 2-year licensing process, and will "develop and implement pilot projects to test a 2-year process" within 180 days, "if practicable.,"102 While the Act only requires FERC implement the pilot projects if a 2-year licensing process is deemed practicable, it does require FERC to give a basis for the determination that it is not practicable and to make recommendations to Congress as to how the issues can be rectified. ${ }^{103}$

95. Id.

96. Id.

97. Id.

98. $I d$.

99. Id. $\S 6(\mathrm{a})$.

100. Id. The two-year process is to include all activities from pre-application through issuance of a license. Id.

101. Id. $\S 6(\mathrm{~b})$.

102. Id.

103. Id. $\S 6(\mathrm{~d})$. The Act provides:

If the Commission determines that no pilot project ... is practicable because no 2-year process is practicable, not later than 240 days after the date of enactment of this Act, the Commission shall submit to the Committee on Energy and Commerce of the House of Representatives and the Committee on Energy and Natural Resources of the Senate a report that --

(A) describes the public comments received as part of the initial workshop held .... and

(B) identifies the process, legal, environmental, economic, and other issues that justify the determination of the Commission that no 2-year process is practicable, with recommendations on how Congress may address or remedy the identified issues. 
Within three years of implementation of a pilot project FERC will hold another workshop and "solicit public comment on the effectiveness of each tested 2-year process." 104 Within sixty days after the final workshop, FERC will report the outcomes of the pilot projects to Congress and outline how the Commission intends to adopt policies and regulations to implement a 2year process. ${ }^{105}$ The Act encourages coordination between FERC, other federal agencies, and the states by requiring that FERC "to the extent practicable, enter into a memorandum of understanding with any applicable Federal or State agency to implement a pilot project.,"106

In addition to the Hydropower Regulatory Efficiency Act, President Obama also signed into law the Bureau of Reclamation Small Conduit Hydropower Development and Rural Jobs Act. ${ }^{107}$ The Act amends the Reclamation Project Act of 1939 and authorizes the Secretary of Interior to enter into contracts for small conduit development on existing facilities owned by the Bureau of Reclamation. ${ }^{108}$ When determining whether to enter into a "lease of power privilege," Reclamation must look at whether the proposed hydropower facility is (1) compatible with the current use and purpose of the conduit and (2) will not "create any unmitigated financial or physical impacts to the project or division involved."109 If so determined, Reclamation must first offer the lease of power privilege to the irrigation

104. Id. $\S 6(\mathrm{~b})$.

105. Id. $\S 6(\mathrm{~d})$. The Act provides:

If the Commission develops and implements pilot projects involving a 2-year process, not later than 60 days after the date of completion of the final workshop ... the Commission shall submit to the Committee on Energy and Commerce of the House of Representatives and the Committee on Energy and Natural Resources of the Senate a report that --

(A) describes the outcomes of the pilot projects;

(B) describes the public comments from the final workshop on the effectiveness of each tested 2-year process; and

(C)(i) outlines how the Commission will adopt policies under existing law (including regulations) that result in a 2 -year process for appropriate projects;

(ii) outlines how the Commission will issue new regulations to adopt a 2-year process for appropriate projects; or

(iii) identifies the process, legal, environmental, economic, and other issues that justify a determination of the Commission that no 2-year process is practicable, with recommendations on how Congress may address or remedy the identified issues.

Id.

106. Id. See Warren, supra note 10 , at $972-75$, for a more thorough discussion of the benefits of states entering into MOUs with FERC for small hydropower development.

107. Bureau of Reclamation Small Conduit Hydropower Development and Rural Jobs Act, Pub. L. No. 113-24, 127 Stat. 498 (2013) (codified at 43 U.S.C. $\S \S 485 k, 485$ h).

108. Id. $\S 2(5)$. "The term 'small conduit hydropower' means a facility capable of producing 5 megawatts or less of electric capacity." Id.

109. Id. 
district or water user association that is either operating the conduit or receiving water from the conduit. ${ }^{110}$ The irrigation district or water user association will then have a "reasonable time" to accept or reject the offer. ${ }^{111}$ If it is rejected, Reclamation may then offer a lease of power privilege to other interested parties. ${ }^{112}$ Reclamation, however, must continue to consult with the irrigation district or water association to ensure development will "adequately protect the planning, design, construction, operation, maintenance, and other interests of the United States and the project or division involved." "113 Environmental assessments will not be required for these facilities, as the Act allows Reclamation to apply the categorical exclusion for review under the National Environmental Policy Act of $1969 .^{114}$

The overarching goal of these two Acts is to help alleviate some of the barriers to development of small hydropower on existing infrastructure. "Over the past three years, leaders on Capitol Hill have been working in a bipartisan manner to advance these commonsense solutions to the real challenges faced by developers who seek to maximize the benefits of water infrastructure. ${ }^{115}$ Now that the trail is being blazed for licensing reform, states should take this as an opportunity to become more involved in the licensing process for small hydropower. States should seek to, where appropriate, enter into agreements with FERC to coordinate efforts to develop a more efficient process. Over the last several years, FERC has showed its willingness to enter into various memorandums of understanding (MOUs) with states and other governmental entities for the purpose of hydropower or hydrokinetic development. ${ }^{16}$ Furthermore, as noted

110. Id.

111. Id.

112. Id.

113. Id.

114. Id. The Act does not exclude from review any transmission line siting necessary to connect the hydropower generation to the grid. Id.

115. Senate Energy Committee Passes Hydroelectric Power Bills to Full Senate for Voting, supra note 89.

116. See Fed. Energy Regulatory Comm'n, Memorandum of Understanding BETWEen THE U.S. DEP'T OF ENERGY AND THE FEDERAL ENERGY REGULATORY COMMISSION (2013), archived at http://perma.cc/G4FK-6BWJ. Colorado, Maine, New York, Washington, Oregon and California have entered into some form of memorandum of understanding with FERC for development of hydrokinetic, wave or tide power. Id. In addition, California is currently in discussions with FERC with regard to entering into a MOU for the purposes of "coordination of pre-application activities for non-federal hydropower proposals in California." TammY Vallejo, Draft MEMORANDUM OF UNDERSTANDING BETwEEN THE FEDERAL ENERGY REGULATORY COMMISSION AND THE CALIFORNIA STATE WATER RESOURCES CONTROL BoARd CONCERNING COORDINATION OF PRE-APPliCATION ACTIVITIES FOR NONFEDERAL HydROPOWER PROPOSALS IN CALIFORNIA 1 (2013), archived at http://perma.cc/B4D6-SMFX. The MOU is not limited to small hydropower. It is "focused on traditional hydropower projects, including pumped storage projects, and does not pertain 
previously, in the newly minted Hydropower Regulatory Efficiency Act of 2013, Congress notes the importance of these MOUs by requiring FERC to, if practicable, enter into MOUs with states to implement the 2-year licensing pilot projects for facilities on nonpowered dams. ${ }^{117}$ This provision should work to encourage states to get involved with the pilot projects for licensing of small hydropower on existing infrastructure within their states. If the pilot programs are successful, states should look to enter into agreements with FERC for continued, coordinated licensing.

A few years ago, Colorado entered into a MOU with the FERC to help streamline the licensing process for small hydropower. ${ }^{118}$ In its studies the Department of Energy had identified several hundred potential sites in Colorado for the development of small hydropower. ${ }^{119}$ In order to develop those sites in an efficient and cost-effective manner, Colorado and FERC agreed to a pilot program whereby Colorado would assume prescreening and consultation duties for certain qualifying projects. ${ }^{120}$ The focus of this pilot project is on the development of small ( $5 \mathrm{MW}$ or less) facilities on existing infrastructure (although it also includes certain qualifying facilities on non-federal conduits and natural water features). ${ }^{121}$ In general, a qualifying project will satisfy the following:

- The project will be located within an existing water delivery system;

- The project will use existing infrastructure, including points of diversion and discharge;

to offshore non-federal hydrokinetic projects." Id. at $1 \mathrm{n} .1$. The intent of the MOU is streamlining the process and allowing the state to conduct "Pre-Application Activities, includ[ing] consultation, environmental scoping, study planning, and submittal of and commenting on the applicant's preliminary licensing proposal." Id. at 1. California sought comments from stakeholders regarding the draft MOU and interestingly, some stakeholders did not believe that the MOU would help streamline the process at all. See Letter from Dennis J. Herrera, City Attorney, City and County of San Francisco, to Tammy Vallejo, State Water Resources Control Board (July 8, 2013), archived at http://perma.cc/9XCXNKZX; see also Letter from Linda Church Ciocci, Exec. Dir., National Hydropower Association, to Tammy Vallejo, State Water Resources Control Board (July 8, 2013), archived at $\mathrm{http}: / /$ perma.cc/E8KT-3G2U.

117. Hydropower Regulatory Efficiency Act of 2013, Pub. L. No. 113-23, § 6(c), 127 Stat. 493 (2013) (codified in scattered sections of 16 U.S.C.).

118. FED. ENERGY REgULATORY COMM'N, MEMORANDUM OF UNDERSTANDING BETWEEN tHe Federal ENERgy Regulatory Commission and tHe State of Colorado Through THE GOVERNOR'S ENERGY OfFICE TO STREAMLINE AND SIMPLIFY tHE AUTHORIZATION OF SMALl SCALE HYDROPOWER PROJECTS 1 (2010), archived at http://perma.cc/DET3-RX5K. The MOU acknowledges that both FERC and the state have an "interest in streamlining and simplifying regulations for authorizing small hydropower projects." Id.

119. Id.

120. Id. at 2. The goal of the MOU is to "simplify the regulatory review of small hydropower projects" so as to timely develop the facilities in an economical and environmentally responsible manner. $I d$.

121. Id. 
- There will be no increased stream diversions;

- The project will be entirely contained by existing waterway structures;

- The primary purpose of the infrastructure will remain, e.g., most commonly municipal [sic] water supply and irrigation;

- There will be no significant change in operation of the infrastructure;

- The water delivery system has all necessary water rights, permits, licenses or other approvals required by any local, state, or federal authority;

- The project will not adversely affect water quality;

- The project will not adversely affect fish passage;

- The project will not adversely affect a threatened or endangered species;

- The project will not adversely affect a cultural resource;

- The project will not adversely affect a recreational resource; and

- The project will meet all of the other requirements for either a conduit or a $5 \mathrm{MW}$ exemption. ${ }^{122}$

Once Colorado officials certify that a project qualifies for the program, they work with the applicant to complete the pre-application and consultation processes before the application is submitted to FERC for final approval. ${ }^{123}$ FERC then has thirty days to act upon the application. It can request additional information, issue a deficiency letter, or issue a license for the facility. ${ }^{124}$ Preliminary results from the pilot project showed a decrease in the time to license a small project from years to months and an average savings of up to $\$ 100,000 .{ }^{125}$ Prior to entering the MOU, twenty-six small hydro licenses had been issued in Colorado in the previous thirty years. ${ }^{126}$ After instating the pilot program, Colorado had prescreened twenty-six projects in one year. ${ }^{127}$ While Colorado has been somewhat

122. Id.at 3.

123. Id at 5; see also Warren, supra note 10 , at $972-75$, for a more thorough discussion on the Memorandum of Understanding and the pilot project.

124. FED. ENERGY REGULATORY COMM'N, supra note 118, at 5.

125. Warren, supra note 10 , at 974 .

126. Id. at 973 .

127. See Colo.'s Renewable Energy Dev. Team (REDT), Streamlining Small Hydro Power Permitting: An Infrastructure and Economic Opportunity, Presented at the 2012 
successful in its attempts to license small hydropower within its state, much work remains to be done at the federal level. At the very least, Colorado's pilot project has "been successful in raising awareness and coordination among federal and state environmental agency officials regarding federal hydro permitting processes." 128

Most stakeholders recognize that development of small hydro, low flow hydro or hydrokinetic power is a "win-win situation: no carbon emissions and a negligible local environmental footprint." ${ }^{29}$ Unfortunately, most stakeholders likewise recognize that licensing for these types of projects has historically been cost and time-prohibitive to the investor. ${ }^{130}$ The proverbial tide, however, is now beginning to turn and federal and state agencies are recognizing the need to embrace exemptions for certain small hydropower licensing and more efficient licensing for others. States should take this opportunity to enter into MOUs and coordinate these efforts so as to be on the forefront of small hydropower generation.

\section{CONCLUSION}

Hydropower is getting a second chance to prove it can be a sustainable, environmentally-friendly source of abundant renewable energy. ${ }^{131}$ According to the Department of Energy, "by utilizing currently untapped resources, the United States could add approximately 60,000 megawatts of new hydropower capacity by $2025 .{ }^{\prime 132}$ In tapping these resources, state and federal regulatory agencies should focus development efforts on existing infrastructure located near populated areas. Small and low flow hydropower facilities can be placed in conduits, canals, locks, and other areas that are less affected by climate change and have less likelihood of creating additional environmental impacts. And, if developed near populated areas, the facilities work as renewable distributed energy to power local customer needs. Strategically placed distributed energy can be less susceptible to large-scale blackouts and damage as a result of storms.

ASERTTI/NASEO State Energy Policy and Technology Outlook Conference, at 13 (Feb. 9 , 2012), archived at http://perma.cc/X96M-R7R5.

128. Kurt Johnson, Big Progress for Small Hydro Permitting Reform (Apr. 1, 2013), http://www.hydroworld.com/articles/hr/print/volume-32/issue-3/articles/big-progress-for-smallhydro-permitting-reform.html, archived at http://perma.cc/9U92-AMZX.

129. Lea Kosnik, The Potential for Small Scale Hydropower Development in the US, 38 ENERGY POLICY 5512, 5512 (2010), archived at http://perma.cc/TF3Q-UZH3.

130. See 159 Cong. REC. 47, p. 1886 (2013) (statement of Rep. Tom McClintock), archived at $\mathrm{http}: / /$ perma.cc/DDR9-N3Z2.

131. U.S. Dep't of ENERgy, Wind \& Water Power Program, An Assessment of ENERGY POTENTIAL AT NON-POWERED DAMS IN THE UNITED STATES 5 (2012), archived at http://perma.cc/67PM-RT6F. "Hydropower has an installed generating capacity considerably greater than any other renewable electricity technology." $1 d$.

132. Hydropower Regulatory Efficiency Act of 2013, Pub. L. No. 113-23, § 2(5), 127 Stat. 493 (2013) (codified in scattered sections of 16 U.S.C.). 
In addition to strategic placement of these small hydropower facilities, federal and state regulatory agencies should work together through MOUs for a more streamlined licensing approach to these small projects. The Hydropower Regulatory Efficiency Act and the Bureau of Reclamation Small Conduit Hydropower Development and Rural Jobs Act of 2013 are great first steps in removing conduits from federal licensing requirements and initiating a pilot program for studying a 2-year process for licensing small hydropower on existing non-powered dams. States should take the appropriate steps to coordinate with FERC for the expeditious development of small and low flow hydropower, at the most appropriate and sustainable sites. 


\section{Indiana}

\section{International}

\& Comparative

Law Review vol. $24 \quad$ No. $2 \quad 2014$

\section{Џ $\mid \begin{aligned} & \text { ROBERT H. MCKINNEY } \\ & \text { SCHOOL OF LAW }\end{aligned}$ \\ IUPUI \\ INDIANA UNIVERSITY \\ Indianapolis}

\section{Indiana University Robert H. McKinney School of Law}

Lawrence W. Inlow Hall, 530 West New York Street, Indianapolis, IN 46202 
The Indiana International and Comparative Law Review publishes professional and student scholarly articles in fields of international or comparative law. The Review welcomes submissions of scholarly legal articles on those topics.

The ideas, views, opinions, and conclusions expressed in articles appearing in this publication are those of the authors and not those of the Review or of Indiana University Robert H. McKinney School of Law.

Currently, the Review is published twice per year. The cost of a single issue is $\$ 9.00$, and subscription rate is $\$ 18.00$ per volume. The annual subscription rate for a foreign subscriber is $\$ 21.00$.

Inquiries regarding submission of articles and comments or subscription may be directed to:

Indiana International \& Comparative Law Review Lawrence W. Inlow Hall 530 West New York Street Indianapolis, IN 46202 (317) 274-1050 (317) $274-8825$ (fax)

\section{COPYRIGHT AND FAIR USE}

Copyright (C) 2014 by the Trustees of Indiana University

Except where expressly noted in this publication, permission is granted to reproduce, distribute, or display individual works from this publication in whole or in part for nonprofit educational purposes. All copies made, distributed, or displayed for such purposes must carry copyright notice of the author and the source of the work on every copy, and each copy may be distributed only at or below cost. The permission herein granted is in addition to rights of reproduction conferred by Sections 107, 108, and other provisions of the U.S. Copyright Act and its amendments.

The Review is printed and distributed by Western Newspaper Publishing, Co., Inc., 537 E. Ohio St., Indianapolis, IN 46204-2173. 


\section{Indiana}

\section{International \\ \& Comparative \\ Law Review}

The Indiana International \& Comparative Law Review, published by the Indiana University Robert H. McKinney School of Law since 1991, is a studentedited law journal that provides a forum for the discussion and analysis of contemporary issues in public and private international law. The Review publishes articles by prominent legal scholars, practitioners, and policy makers around the world, as well as student-written notes and comments.

The Review is published twice annually, with a symposium issue devoted to a specific topic of international or comparative law published intermittently. Past symposium topics have included political and social aspects of Italian law, various aspects of Chinese law, and international terrorism in the twenty-first century.

Name

School/Firm/Business

Address

City, State, Zip Code

Subscriptions within the U.S. are $\$ 18.00$ per year and outside the U.S. are $\$ 21.00$ per year. I enclose $\$$ for subscription(s) to the Indiana International \& Comparative Law Review. Please make your check payable to the Indiana International \& Comparative Law Review.

Mail to: $\quad$ Executive Production Editor

Indiana International \& Comparative Law Review

Lawrence W. Inlow Hall

530 West Street

Indianapolis, IN 46202-3225 



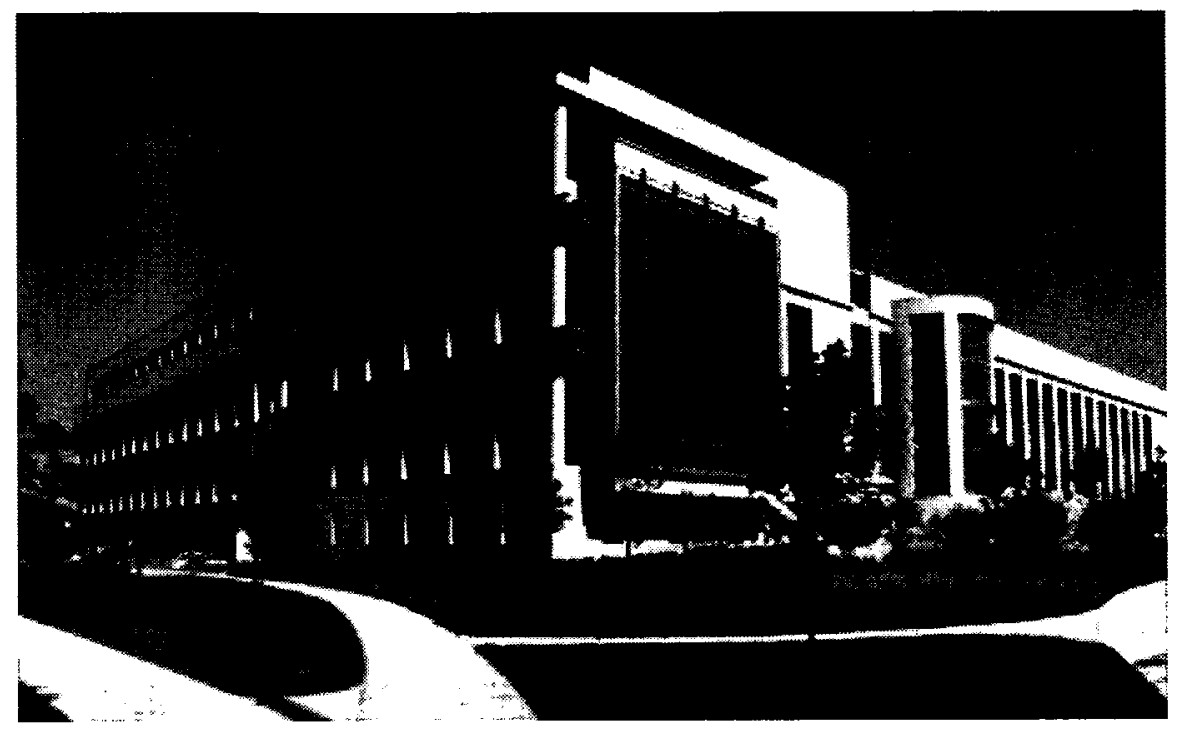

Please enter my subscription

to the

INDIANA LAW REVIEW

Name

Address

Enclosed is $\$$ for subscription(s)

Mail to: ATTN: Editorial Specialist

at

INDIANA LAW REVIEW

INDIANA UNIVERSITY ROBERT H. MCKINNEY

SCHOOL OF LAW

Lawrence W. Inlow Hall

530 West New York Street

Indianapolis, Indiana 46202-3225

For an academic year, the subscription rate for four issues is:

Domestic, \$30; Foreign, \$35; Student, $\$ 20$

Single Issue, $\$ 10$; Survey Issue $\$ 20$

Symposium Issue, $\$ 15$ 
. 


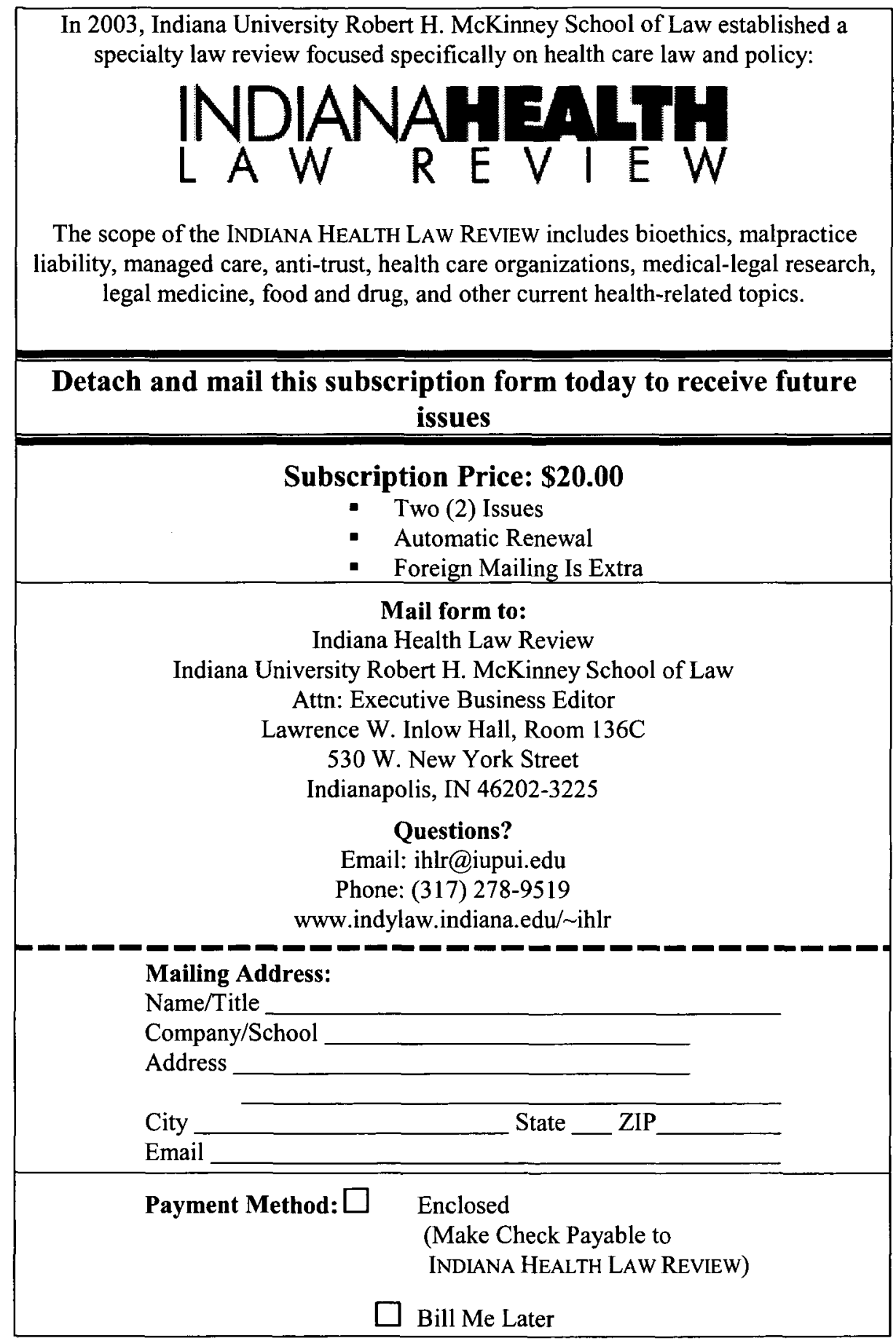





\title{
Indiana University Robert H. McKinney School of Law 2013-2014 ADMINISTRATIVE OFFICERS AND FACULTY
}

\author{
Administrative Officers
}

MiChael A. MCRoBbie, President of the University. Ph.D., Australian National University.

CHARLES R. BANTZ, Chancellor, Indiana University-Purdue University-Indianapolis. B.A., M.A., University of Minnesota; Ph.D., Ohio State University.

ANDREw R. KLeIn, Dean and Paul E. Beam Professor of Law. B.A., University of

Wisconsin; J.D., Emory University School of Law.

Antony Page, Vice Dean and Professor of Law. B. Comm., McGill University; M.B.A., Simon Fraser University; J.D., Stanford Law School.

Karen E. Bravo, Associate Dean for Graduate Studies and International Affairs, Professor of Law, John S. Grimes Fellow; Dean's Fellow. B.A., The University of the West Indies; J.D., Columbia University School of Law; LL.M., New York University School of Law.

Patricia K. KInNeY, Assistant Dean for Admissions. B.S., Purdue University; J.D., Indiana University Robert H. McKinney School of Law.

JOHNNY D. PRYOR, Assistant Dean for Student Affairs. B.A., Wittenberg University; J.D., Indiana University Maurer School of Law.

JonNa KanE MACDOUGALl, Assistant Dean for External Affairs and Alumni Relations. B.A., M.A., Indiana University; J.D., Indiana University Robert H. McKinney School of Law.

Chasity Q. ThOmpson, Assistant Dean for Professional Development. A.S., B.A., Alabama State University; M.B.A., Auburn University; J.D., Indiana University Robert H. McKinney School of Law.

MARK V. WUNDER, Assistant Dean for Development. B.S., J.D., University of Iowa.

Elzabeth Allington, Director of Communications and Creative Services. B.A., Indiana University; M.A., M. Phil., New York University.

TERESA (TERRI) J. CUELlAR, Director of Technology Services. B.S., St. Bonaventure University, New York.

VIRGINIA MARSCHAND, Director of Administrative and Fiscal Affairs. B.S., Indiana University-Kokomo; M.P.A., Indiana University Purdue University-Indianapolis; J.D., Indiana University Robert H. McKinney School of Law.

JOHN R. SCHAIBLEY, III, Executive Director of the Center for Intellectual Property Law and Innovation and Adjunct Professor of Law. B.A., Purdue University; J.D., Indiana University Maurer School of Law.

SonJA RICE, Director of Special Projects. B.A., Purdue University; J.D., Indiana University Robert H. McKinney School of Law.

LISA SCHRAGE, Director of Development Services. B.S., Marian University.

LaWanda W. WARD, Director of Pro Bono and Public Interest Programs. B.A., Murray State University; M.A., Illinois State University; M.S., Old Dominion University; J.D., Indiana University Robert H. McKinney School of Law.

ANTHONY MASSERIA, Associate Director for Graduate Programs. B.A., Hanover College; M.S. Ed., Indiana University.

SEAN SOUTHERN, Associate Director, Office of Professional Development. B.A., Ball State University; M.A., DePaul University; J.D., Loyola University Chicago School of Law.

CARlota TOLEDO, Associate Director of Student Affairs. A.B., University of Chicago; J.D., DePaul University College of Law.

SUSAN K. AGNEW, Assistant Director of Student Affairs. Clark College.

WILlIAM J. BAKER, Assistant Director of Technology Services. B.S., Purdue University.

Susan Bushue-Russell, Assistant Business Manager. A.A.S., Lakeland College; B.S., Eastern Illinois University.

AMY ELSON, Assistant Director, Hall Center for Law and Health. B.A., M.A., Indiana University; J.D., Indiana University Maurer School of Law.

Amanda Gallaga, Assistant Director of Recruitment. B.A., Trinity University. 
NOAH JOSEPH, Assistant Director of Graduate Admissions. B.A., Miami University; J.D., Indiana University Maurer School of Law.

LEANDRA Ross, Assistant Director of Financial Aid. B.S., M.P.A., Indiana University.

EMILY TRINKLE, Assistant Director of Advancement. B.S., Indiana University.

\section{Faculty}

CYNTHIA M. ADAMS, Clinical Professor of Law. B.A., Kentucky Wesleyan College; J.D., Indiana University Robert H. McKinney School of Law.

JUdiTH Ford ANSPACH, Professor of Law and Director, Ruth Lilly Law Library. B.S., M.L.S., Kent State University; J.D., Mississippi College School of Law.

CYNTHIA A. BAKer, Clinical Professor of Law and Director, Program on Law and State Government. B.A., J.D., Valparaiso University.

GERALD L. BEPKO, Indiana University-Purdue University-Indianapolis Chancellor Emeritus, Indiana University Trustee Professor and Professor of Law. B.S., Northern Illinois University; J.D., ITT/Chicago-Kent College of Law; LL.M., Yale Law School.

Shawn BoYne, Professor of Law, Co-Chair, Global Crisis Leadership Forum, Dean's Fellow; Grimes Fellow, DRIVE Fellow. B.A., Cornell University; M.B.A., University of Minnesota; J.D., University of Southern California's Gould School of Law, M.A., Ph.D., University of Wisconsin; LL.M., Justus-Liebig-Universität.

RoBERT BROoKIns, Professor of Law. B.S., University of South Florida; J.D., Ph.D., Cornell University.

JefFreY O. COOPER, Associate Professor of Law. A.B., Harvard University; J.D., University of Pennsylvania Law School.

ERIC R. DANnENMAIER, Professor of Law, Dean's Fellow; Director, Environmental, Energy and Natural Resources Law Program. B.A., Drury College; J.D., Boston University; LL.M., Columbia University; M. St., Oxford University.

JAMES D. DimITRI, Clinical Professor of Law. B.S., Indiana University; J.D., Valparaiso University School of Law.

JeNnifer A. DROBAC, Professor of Law. B.A., M.A., Stanford University; J.D., J.S.D., Stanford Law School.

Yvonne M. Dutton, Associate Professor Law. B.A., Columbia University; M.A., Ph.D., University of Colorado at Boulder; J.D., Columbia Law School.

George E. Edwards, Carl M. Gray Professor of Law; Director, Program in International Human Rights Law; John S. Grimes Fellow. B.A., North Carolina State University; J.D., Harvard Law School.

Frank EmmerT, John S. Grimes Professor of Law; Executive Director, Center for International and Comparative Law; Director, International and Comparative Law track, LL.M. Program. Erstes Juristisches Staatsexamen (J.D.), University of Munich Law School; LL.M., The University of Michigan Law School; Ph.D., University of Maastricht; Diploma, European University Institute.

Nicholas GeORgakopoulos, Harold R. Woodard Professor of Law. Ptyhion Nomikis, Athens University School of Law; LL.M., S.J.D., Harvard Law School.

CARRIE HAGAN, Clinical Associate Professor of Law. B.A., University of Kansas; J.D., University of Cincinnati College of Law.

John Lawrence Hill, Professor of Law, Adjunct Professor of Philosophy, Grimes Fellow. B.A., Northern Illinois University; J.D., Ph.D., Georgetown University.

MaX HuffMan, Associate Professor of Law and Dean's Fellow. B.A., Comell University; J.D., University of Cincinnati College of Law.

Lawrence A. Jegen, III, Thomas F. Sheehan Professor of Tax Law and Policy. B.A., Beloit College; J.D., M.B.A., University of Michigan; LL.M., New York University School of Law.

RoBert A. KaTZ, Professor of Law. A.B., Harvard College; J.D., University of Chicago Law School.

LinDA KelLY, M. Dale Palmer Professor of Law. B.A., J.D., University of Virginia.

NoRMAN LeFsTEIN, Professor of Law and Dean Emeritus. LL.B., University of Illinois College of Law; LL.M., Georgetown University Law School. 
GeraRd N. Magliocca, Samuel R. Rosen Professar of Law; Director, Intellectual Property Law track, LL.M. Program.. B.A., Stanford University; J.D., Yale Law School. ALLISON MARTIN, Clinical Professor of Law. B.S., J.D., University of Illinois.

DEBORAH MCGREGoR, Clinical Professor of Law; Assistant Director of Legal Analysis, Research and Communication; Director, Master of Jurisprudence Program. B.A., University of Evansville; J.D., Georgetown University Law Center.

EMIL Y MORRIS, Associate Professor of Law and Dean's Fellow. A.B., Harvard University; J.D., University of Michigan Law School.

Novella NedefF, Clinical Associate Professor of Law. B.A., J.D., Indiana University.

JAMES P. NEHF, Cleon H. Foust Fellow, John S. Grimes Fellow, and Professor of Law. B.A., Knox College; J.D., University of North Carolina Law School.

DAVID ORENTLICHER, Samuel R. Rosen Professor of Law and Co-Director of the William S. and Christine S. Hall Center for Law and Health. B.A., Brandeis University; J.D., M.D., Harvard University.

JoANnE ORR, Clinical Professor of Law and Co-Director of Law School Clinical Programs. B.S., Indiana State University; J.D., California Western School of Law.

Michael J. PitTs, Professor of Law and Dean's Fellow. B.S.J., Northwestern University; J.D., Georgetown University Law Center.

Fran Quigley, Clinical Professor of Law, Health and Human Rights Clinic; Director, International Human Rights track, LL.M. Program; Senior Advisor, Indiana University Center for Global Health. B.A., Hanover College; M.A., Indiana University; J.D., Indiana University Robert H. McKinney School of Law.

GARY R. ROBERTS, Dean Emeritus and Gerald L. Bepko Professor of Law. B.A., Bradley University; J.D., Stanford University.

FLoRENCE WAGMAN RoISMAN, William F. Harvey Professor of Law. B.A., University of Connecticut; LL.B., Harvard Law School.

JoAn M. RUHTENBERG, Clinical Professor of Law and Director of Legal Analysis, Research and Communication. B.A., Mississippi University for Women; J.D., Indiana University Robert H. McKinney School of Law.

MARGARET RYNZAR, Associate Professor of Law and Dean's Fellow. B.A., University of Chicago; M.A., Jagiellonian University; J.D., University of Notre Dame Law School.

JoEl M. SCHUMM, Clinical Professor of Law and Director, Judicial Externship Program. B.A., Ohio Wesleyan University; M.A., University of Cincinnati; J.D., Indiana University Robert H. McKinney School of Law.

LEA SHAVER, Associate Professor of Law and Dean's Fellow. B.A., M.A., University of Chicago; J.D., Yale Law School.

LAHNY R. SILVA, Associate Professor of Law and Dean's Fellow. B.A., M.A., Boston University; J.D., University of Connecticut School of Law; LL.M., University of Wisconsin Law School.

Ross SILVERMAN, Professor of Public Health and Law (Secondary Appointment). B.A., Indiana University; J.D., Boston University School of Law; M.P.H., Boston University School of Public Health.

Frank Sullivan, JR., Professor of Practice. A.B., Dartmouth College; J.D., Indiana University Maurer School of Law; LL.M., University of Virginia School of Law.

Margaret C. TARKIngton, Associate Professor of Law and Dean's Fellow. B.A., Brigham Young University; J.D., J. Reuben Clark Law School, Brigham Young University.

NICHOLAS TERRY, Hall Render Professor of Law; Co-Director of the William S. and Christine S. Hall Center for Law and Health; Director, Health Law, Policy and Bioethics track, LL.M. Program. B.A., Kingston University; LL.M., Corpus Christi College, University of Cambridge.

Carlton Mark Waterhouse, Professor of Law and Dean's Fellow. B.S., Pennsylvania State University; J.D. with honors, Howard University School of Law; M.T.S., Emory University, Chandler School of Theology; Ph.D. with honors, Emory University.

Frances Watson, Clinical Professor of Law and Co-Director of Law School Clinical Programs. B.S., Ball State University; J.D., Indiana University Robert H. McKinney School of Law. 
James Patrick White, Professor of Law. A.B., University of Iowa; J.D., LL.M., George Washington University Law School.

LlOYD T. WILSON, JR., Professor of Law; Director, Joint Center for Asian Law Studies; Director, Chinese Law Summer Program; Director, American Law for Foreign Lawyers track, LL.M. Program. B.A., Wabash College; M.A., Duke University; J.D., Indiana University Maurer School of Law.

DANA R.H. WINTERS, Associate Professor Law and Dean's Fellow. B.A., Brown University; M.A., Ph.D., Harvard University; J.D., New York University School of Law.

R. GEORGE Wright, Lawrence A. Jegen III Professor of Law. A.B., University of Virginia; Ph.D., Indiana University; J.D., Indiana University Robert H. McKinney School of Law.

\section{Emeriti Faculty}

Thomas B. ALLINGTon, Professor of Law Emeritus. B.S., J.D., University of Nebraska; LL.M., New York University School of Law.

EDWARD P. ARChER, Professor of Law Emeritus. B.M.E., Renesselaer Polytechnic Institute; J.D., LL.M., Georgetown University Law School.

JAMES F. BAILEY, III, Professor of Law Emeritus. A.B., J.D., M.A.L.S., The University of Michigan.

PaUl N. Cox, Centennial Professor of Law Emeritus. B.S., Utah State University; J.D., University of Utah College of Law; LL.M., University of Virginia School of Law.

Clyde HaRrison CRocketT, Professor of Law Emeritus. A.B., J.D., University of Texas; LL.M., University of London (The London School of Economics and Political Science).

Debra A. Falender, Professor of Law Emerita. A.B., Mount Holyoke College; J.D., Indiana University Robert $\mathrm{H}$. McKinney School of Law.

DAVID A. FUNK, Professor of Law Emeritus. A.B., College of Wooster; J.D., Case Western Reserve University School of Law; M.A., The Ohio State University; LL.M., Case Western Reserve University; LL.M., Columbia Law School.

Paul J. Galanti, Professor of Law Emeritus. A.B., Bowdoin College; J.D., University of Chicago Law School.

Helen P. GaRfield, Professor of Law Emerita. B.S.J., Northwestern University; J.D., University of Colorado School of Law.

JefrReY W. Grove, Professor of Law Emeritus. A.B., Juniata College; J.D., George Washington University Law School.

William F. HaRveY, Carl M. Gray Professor of Law \& Advocacy Emeritus. A.B., University of Missouri; J.D., LL.M., Georgetown University Law School.

W. William Hodes, Professor of Law Emeritus, A.B., Harvard College; J.D., Rutgers University School of Law-Newark.

William ANDREw KerR, Professor of Law Emeritus. A.B., J.D., West Virginia University; B.D., Duke University; LL.M., Harvard Law School.

Eleanor DeARMan KInNEY, Hall Render Professor of Law, Co-director of the William $S$. and Christine S. Hall Center for Law and Health Emerita. B.A., Duke University; M.A., University of Chicago; J.D., Duke University School of Law; M.P.H., University of North Carolina.

William E. Marsh, Professor of Law Emeritus. B.S., J.D., University of Nebraska.

SUSANAH M. MEAD, Professor of Law Emerita. B.A., Smith College; J.D., Indiana University Robert H. McKinney School of Law.

H. KATHLEen PATCHEL, Associate Professor Law Emerita. A.B., Huntingdon College; J.D., University of North Carolina; LL.M., Yale Law School.

Ronald W. POLSTON, Professor of Law Emeritus. B.S., Eastern Illinois University; LL.B., University of Illinois College of Law.

KENNETH M. STROUd, Professor of Law Emeritus. A.B., J.D., Indiana UniversityBloomington.

JAMES W. TORKE, Carl M. Gray Professor of Law Emeritus. B.S., J.D., University of Wisconsin. 
JAmes Patrick White, Professor of Law Emeritus. A.B., University of Iowa; J.D., LL.M., George Washington University Law School.

LAWRENCE P. WILKInS, William R. Neale Professor of Law Emeritus. B.A., The Ohio State University; J.D., Capitol University Law School; LL.M., University of Texas School of Law.

MARY Therese WOLF, Clinical Professor of Law Emerita. B.A., Saint Xavier College; J.D., University of Iowa College of Law.

\section{Ruth Lilly Law Library Faculty}

JUDITH FoRd ANSPACH, Professor of Law and Director, Ruth Lilly Law Library. B.S., M.L.S., Kent State University; J.D., Mississippi College School of Law.

SuSAN David DEMAINE, Research \& Instruction Librarian. B.A., Pennsylvania State University; M.S.L.S., J.D., University of Kentucky.

RichARD HuMPHREY, Reference Librarian. A.A., Brewton-Parker Junior College; B.A., Georgia Southwestern College; M.L.S., University of Kentucky.

Wendell E. JohnTING, Cataloging and Government Documents Librarian. A.B., Taylor University; M.L.S., Indiana University.

BENJAMIN J. KEELE, Research and Instruction Librarian. B.A., University of NebraskaLincoln; J.D., Indiana University Maurer School of Law; M.L.S., Indiana University.

CATHERINE LeMMER, Head of Information Services. B.A., Lawrence University; J.D., University of Wisconsin; M.S., University of Illinois.

ChrIS E. LoNG, Cataloging Librarian. B.A., Indiana University; M.A., Indiana University; M.L.S., Indiana University.

Miriam A. MurPHY, Associate Director. B.A., Purdue University; J.D., M.L.S., Indiana University-Bloomington. 


$$
\text { , }
$$




\section{W $\mid \begin{aligned} & \text { ROBERT H. MCKINNEY } \\ & \text { SCHOOL OF LAW }\end{aligned}$ IUPUI INDIANA UNIVERSITY \\ Indianapolis}

\section{Indiana International \& Comparative Law Review, Volume XXIV 2013-2014}

\section{Editor-in-Chief}

SUKRAT BABER

\section{Executive Managing Editor}

ZACHARY AHONEN

Executive Notes Development Editor

ALYSSA TAYLOR

Executive Articles Development Editor

NICHOLAS JOHNSTON

Symposium Publication Editor

DAVID DICKMEYER
Executive Production Editor

TARAH M.C. BALDWN

\section{Executive Notes Editor}

SARAH HARRELL

Executive Articles Editor

SEAN DENAULT

\section{Live Symposium Coordinator}

EMMA MAHERN

JON BURNS

KATELYN HOLUB

LANE TUTTLE

\section{Editorial Board}

ANDREW EMHARDT

MARIANNE LUU

Associate Editors
KYLE FORGUE PATRICK MCINTYRE GRAHAM YOUNGS

\section{JOSHUA BURRESS}

KYLE CRAY

ElaiNA STREISEL
CARRIE BRENNAN
RYAN SCHWIER
BRYAN LAMB
DRAKE LAND

ELAINA STREISEL RYAN SCHWIER DRAKE LAND

\section{Student Note Candidates}

EMILY STEEB

BEAU BROWNING

AMANDA FIORINI

SAHAND RAJABZADEH

HEATHER GRIMSTAD

AARON WILLIAMSON
SHARON ROBERTS

LAURA WALKER

PAUL BABCOCK

MALLORY WILSON

JONATHAN BAILEY

KRISTOPHER FRYE
KYLE BURNS

ELLEN QUEEN LINDSAY LLEWELLYN JILLIAN RABE MEGAN CAIN

PETER ELLIOTT

\section{Board of Faculty Advisors}

KAREN BRAVO, CHAIRWOMAN

FRANK EMMERT

GEORGE E. EDWARDS

ANTONY PAGE

JOAN M. RUHTENBERG

LLOYD T. WILSON, JR. 
